Jurnal Indonesia Sosial Teknologi: p-ISSN: 2723 - 6609

e-ISSN : 2745-5254

Vol. 2, No. 6 Juni 2021

\title{
PENGARUH CHALKY PADA POROSITAS DAN PERMEABILITAS RESERVOIR BATUGAMPING BERDASARKAN UJI LABORATORIUM SAMPEL CORE, DARI LAPANGAN "AR"
}

\section{Arief Rahman dan Rani Rahmawati}

Akamigas Balongan Indramayu

Email: arief11rahman@gmail.com,raaniraahmawati2@gmail.com

\section{Abstract}

Reservoir rock porosity determines the volume of oil and gas reserves, while permeability is very important for the radius of oil and gas drain and recovery factor $(R F)$. The purpose of this study is to determine the effect of depth on the porosity of limestone (limestone), the relationship between porosity and permeability, and to determine the effect of the presence of chalk on the sample. core plug limestone on the value of porosity and permeability. The research method used is a Lab Test conducted at theLaboratory Routine Core Analysis (RCAL) at PPPTMBG "Lemigas" Jakarta. The materials used are 21 (twenty one) samples core plugs taken horizontally, described, and ready to be tested, from samples conventional core of a limestone reservoir containing oil (oil reservoir), from the "AR" field. The research steps are measuring the value of porosity (ø) and permeability $(k)$ using a porosimeter-permeameter with helium gas, then plotting a graph of the measurement results, for analysis. As a result,porosity measurements limestone without Chalky lowest at the highest $11.58 \%$ to $23.79 \%$, or just(fair)to very good (verygood), while the porosity of limestone with a Chalky low of $29.20 \%$ highest sd 42, 12\%, or special (excellent).permeability limestone without Chalky the lowestoft $0.5 \mathrm{mD}$ highest sd $10.90 \mathrm{mD}$, or tight(tight)to fair (fair), while the permeability of limestone with a Chalky low of 38.4 Mdhighest sd Md 193.90, or both (good) to very good (very good). The conclusion of this study is that the porosity of carbonate rocks in this case is not affected by depth, the relationship between porosity and permeability in this case is exponentially proportional, and the porosity and permeability values of limestone with the presence of chalky are better than limestones without the presence of chalky.

Keyword: chalky; porosity; permeability.

\footnotetext{
Abstrak

Porositas batuan reservoir menentukan jumlah volume cadangan migas, sedangkan permeabilitas sangat penting untuk radius pengurasan migas dan recovery factor (RF). Tujuan dari penelitian yaitu mengetahui efek kedalaman terhadap porositas batugamping (limestone), hubungan porositas dan permeabilitas, dan mengetahui efek/pengaruh adanya chalk pada sampel core plug batugamping terhadap nilai porositas dan permeabilitas. Metode penelitian yang digunakan adalah Uji Lab yang dilakukan di Laboratorium Routine Core Analysis (RCAL) di PPPTMBG "Lemigas" Jakarta. Bahan yang digunakan adalah 21 (dua puluh satu) sampel core
} 
plug yang diambil secara horizontal, yang sudah di deskripsi, dan siap uji, dari sampel conventional core dari reservoir batugamping yang mengandung minyak bumi (oil reservoir), dari lapangan "AR". Tahapan penelitian yaitu mengukur nilai porositas $(\varnothing)$ dan permeabilitas (k) menggunakan alat porosimeter-permeameter dengan gas helium, kemudian plot grafik hasil pengukuran, untuk dilakukan analisis. Hasilnya, pengukuran porositas limestone tanpa chalky terendah yaitu $11,58 \%$ s.d tertinggi yaitu $23,79 \%$, atau cukup (fair) hingga sangat baik (very good), sedangkan porositas limestone dengan chalky terendah yaitu 29,20\% s.d tertinggi yaitu $42,12 \%$, atau istimewa (excellent). Permeabilitas limestone tanpa chalky terendah yaitu $0,5 \mathrm{mD}$ s.d tertinggi yaitu $10,90 \mathrm{mD}$, atau ketat (tight) hingga cukup (fair), sedangkan permeabilitas limestone dengan chalky terendah yaitu 38,4 $\mathrm{mD}$ s.d tertinggi yaitu $193,90 \mathrm{mD}$, atau baik (good) hingga sangat baik (very good). Kesimpulan penelitian ini yaitu porositas batuan karbonat dalam kasus ini tidak berpengaruh terhadap kedalaman, hubungan porositas dan permeabilitas dalam kasus ini adalah berbanding lurus secara eksponensial, dan nilai porositas dan permeabilitas limestone dengan kehadiran chalky lebih baik dibanding limestone tanpa kehadiran chalky.

Kata kunci: chalky; porositas; permeabilitas.

\section{Pendahuluan}

Porositas dan permeabilitas adalah dua sifat fisik batuan yang sangat penting untuk menyimpan dan mengalirkan/melewatkan minyak dan gas bumi dalam batuan reservoir (wadah) di bawah permukaan bumi. Semakin besar porositas suatu batuan reservoir migas, maka volume/cadangan migas semakin besar, dan semakin besar permeabilitas, maka radius pengurasan migas dan recovery factor atau RF (persentase volume gas yang dapat diambil) dari suatu reservoir, akan semakin besar.

Berdasarkan (Koesoemadinata, 1980), porositas suatu medium atau cukup disebut "porositas" (ø) adalah perbandingan volume rongga-rongga pori (Pore Volume atau PV) terhadap volume total seluruh batuannya (Volume Bulk atau BV). Perbandingan ini biasanya dinyatakan dalam persen (\%). Berikut ini rumus porositas:

$$
\text { Porositas }(\varnothing)=(\mathrm{PV} / \mathrm{BV}) * 100 \%
$$

PV dapat diambil dari BV dikurangi GV atau Grain Volume. Porositas suatu batuan ditentukan berdasarkan data dari analisis batuan inti atau core, logging sumur atau well logging, dan uji sumur atau well testing (Yu \& Menouar, 2015). Berikut ini adalah pembagian atau klasifikasi nilai porositas dalam persen $(\%)$ :

\section{Tabel 1}

Klasifikasi Porositas (Koesoemadinata, 1980)

\begin{tabular}{cl}
\hline Persentase Porositas & Keterangan \\
\hline $0-5 \%$ & Dapat diabaikan (negligible) \\
\hline $5-10 \%$ & Buruk (poor) \\
\hline $10-15 \%$ & Cukup (fair) \\
\hline $15-20 \%$ & Baik (good) \\
\hline $20-25 \%$ & Sangat Baik (very good) \\
\hline
\end{tabular}




\begin{tabular}{ll}
\hline $25 \%$ & Istimewa (excellent) \\
\hline
\end{tabular}

Berdasarkan (Rukmana et al., 2012), permeabilitas batuan (k) merupakan nilai yang menunjukkan kemampuan suatu batuan porous untuk mengalirkan fluida. Satuan permeabilitas adalah Darcy, berdasarkan percobaan Henry Darcy. Definisi batuan mempunyai permeabilitas 1 Darcy menurut hasil percobaan ini adalah apabila batuan mampu mengalirkan fluida dengan laju $1 \mathrm{~cm}^{3} / \mathrm{s}$, berviskositas $1 \mathrm{cp}$, sepanjang $1 \mathrm{~cm}$ dan mempunyai penampang $1 \mathrm{~cm}^{2}$, perbedaan tekanan sebesar $1 \mathrm{~atm}$, ditulis dalam suatu persamaan:

$$
\mathrm{k}=(\mathrm{Q} * \mu) /(\mathrm{A} .(\Delta \mathrm{P} / \Delta \mathrm{L}))
$$

Dimana: $\mathrm{k}=$ Permeabilitas media berpori, darcy

$\mathrm{Q}=$ Debit / laju alir, $\mathrm{cm}^{3} / \mathrm{s}$

$\mu=$ Viskositas fluida, $\mathrm{cp}$

$\mathrm{A}=$ Luas Penampang, $\mathrm{cm}^{2}$

$\Delta \mathrm{P}=$ beda tekanan masuk dan keluar, atm

$\Delta \mathrm{L}=$ panjang media berpori, $\mathrm{cm}$

Berikut ini adalah pembagian atau klasifikasi nilai permeabilitas dalam persen milli darcy atau $\mathrm{mD}$ :

Tabel 2

Klasifikasi Permeabilitas (Koesoemadinata, 1980)

\begin{tabular}{cc}
\hline Rentang Nilai & Keterangan \\
\hline$<5 \mathrm{mD}$ & Ketat $($ tight $)$ \\
\hline $5-10 \mathrm{mD}$ & Cukup $($ fair $)$ \\
\hline $10-100 \mathrm{mD}$ & Baik $($ good $)$ \\
\hline $100-1000 \mathrm{mD}$ & Sangat Baik $($ very good $)$ \\
\hline
\end{tabular}

Diambil dari Schlumberger-Oilfield Glossary (-). Rangkaian pengukuran Routine Core Analysis (analisis batuan inti rutin / dasar, atau disebut RCAL) biasanya dilakukan pada core plug atau whole core atau conventional core (batuan ini konvensional), yang mencakup: porositas, kerapatan butir, permeabilitas horizontal, saturasi fluida dan deskripsi litologi.

Core plug yaitu sebuah plug, atau sampel, diambil dari conventional core untuk dilakukan analisis. Core plug biasanya berdiameter 1 inci hingga 1 1/2 inci [2,5 hingga $3,8 \mathrm{~cm}$ ] dan panjang 1 inci hingga 2 inci $[5 \mathrm{~cm}]$. Core plug biasanya dipotong/diambil tegak lurus dengan sumbu core atau sejajar (horisontal) dengan sumbu, disebut core plug horizontal, dan disebut core plug vertikal, ketika dipotong dari lubang sumur vertikal. Sedangkan whole core atau conventional core (batuan ini konvensional) yaitu bagian lengkap dari core yang dibor secara konvensional.

Dua (2) variabel utama dalam pengukuran porositas adalah BV dan PV pada sampel core. BV dapat dihitung dengan mengetahui ukuran panjang (L) dan diameter 
Pengaruh Chalky pada Porositas dan Permeabilitas Reservoir Batugamping Berdasarkan Uji Laboratorium Sampel Core, dari Lapangan "AR"

(D) sampel core secara langsung, namun untuk mengetahui nilai PV, dan juga permeabilitas, harus dilakukan pengukuran skala laboratorium menggunakan alat

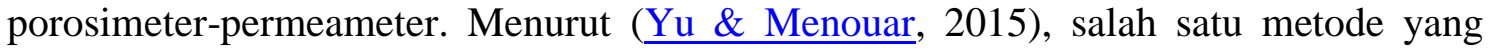
paling banyak digunakan adalah teknik (menggunakan) helium dengan menerapkan hukum Boyle. Beberapa alasan utama yang menggunakan helium daripada gas lain adalah sebagai berikut:

a) Molekul kecilnya dapat menembus pori-pori kecil dengan cepat.

b) Bersifat Inert (tidak reaktif) dan tidak terserap pada permukaan batuan.

c) Dapat dianggap sebagai gas ideal untuk tekanan dan suhu.

d) Dengan difusivitas tinggi, penggunaan helium dapat digunakan untuk menentukan nilai porositas batuan permeabilitas rendah

Batuan karbonat (limestone and dolostone) menyumbang sekitar 50\% produksi minyak dan gas di seluruh dunia (Kadhim \& Al-Sudani, 2020). Batuan Karbonat dapat tergolong kedalaman batuan sedimen kelompok klastik dan juga non-klastik. Batuan karbonat non-klastik diendapkan di laut dangkal (Nichols, 2009). Batugamping (limestone) tersusun dari kalsit $\left(\mathrm{CaCO}_{3}\right)$, dan dolostone tersusun dari dolomit $\left[\mathrm{CaMg}\left(\mathrm{CO}_{3}\right)_{2}\right]$, keduanya adalah batuan karbonat karena sama-sama mengandung radikal karbonat $\left(\mathrm{CO}^{3}\right)^{-2}$. Batugamping (non klastik) dibentuk dari faktor kimia yaitu: reaksi kimia antar unsur, dan biokimia yaitu reaksi kimia antar unsur melibatkan cangkang makhluk hidup disekitarnya, contohnya seperti coral fragment Monroe, S J., Wicander R., 2007).

Tidak seperti kebanyakan reservoir batupasir, yang biasanya mempunyai sistem porositas tunggal (yaitu, pori-pori interparticle) yang sifatnya relatif seragam (homogen), reservoir dalam batuan karbonat umumnya adalah sistem multi-porositas yang secara khas memberikan heterogenitas petrofisika ke batuan reservoir (Kadhim \& Al-Sudani, 2020). Secara umum, nilai porositas suatu batuan reservoir (studi kasus batupasir) akan semakin mengecil seiring bertambahnya kedalaman (Widarsono, 2008). Namun, porositas pada batuan karbonat sangat dipengaruhi oleh fasies atau lingkungan pengendapannya dan proses saat diagenesa (Noventiyanto, 2011).

Bentuk atau jenis rongga pori batuan karbonat menentukan nilai porositas-nya. (Saltwork Consultants Pty Ltd, 2016), memperkenalkan 15 tipe porositas (rongga pori) karbonat yang terbagi dalam dalam tiga (3) kelompok klasifikasi yang saat ini digunakan secara luas di industri minyak dan gas, yaitu Fabric Selective Pores, NonFabric Selective Pores, dan Fabric / Non Fabric Selective. Lihat Gambar 1.

Porositas (disebabkan karena) vugs / vuggy (berlubang) adalah salah satu jenis porositas pada batuan karbonat. Porositas seperti ini berpengaruh signifikan terhadap permeabilitas, penurunan tekanan, dan recovery factor (RF) di reservoir. Uji RCAL (Routine Core Analysis atau analisis batuan inti rutin/dasar) adalah salah satu alat utama untuk menentukan vugs /lubang-lubang (Asgarinezhad et al., 2016). Lihat Gambar 2. 


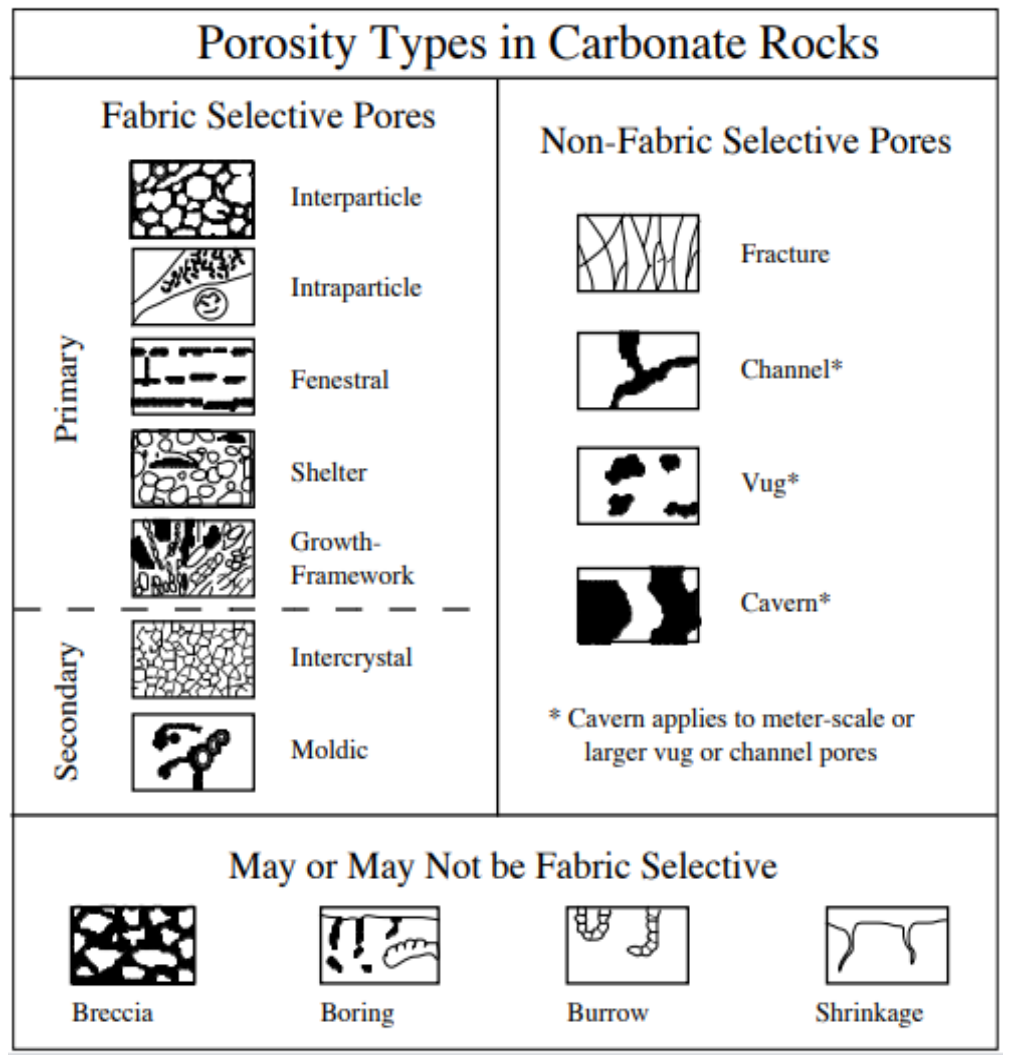

Gambar 1

Tipe porositas dalam batuan karbonat (Hiatt \& Kyser, 2000).

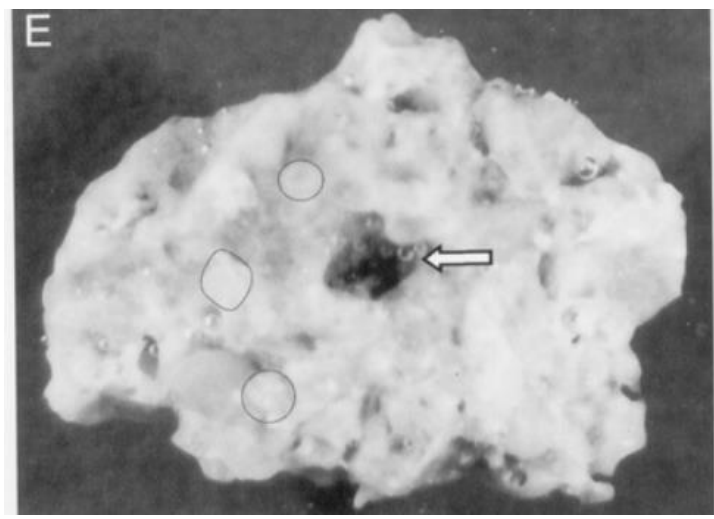

Gambar 2

Contoh rongga pori vug (tanda panah) pada batuan karbonat grainstone (Kadhim \& Al-Sudani, 2020).

Kapur atau Chalk merupakan batuan sedimen karbonat non klastik yang berupa batu gamping yang tersusun dari mineral kalsit. Komposisi kimia kapur adalah kalsium karbonat dan dengan sedikit mineral lanau dan lempung. Ini terbentuk di laut oleh plankton sub-mikroskopis, yang jatuh ke dasar laut dan kemudian dikonsolidasikan dan dikompresi selama diagenesis menjadi batuan (geologyscience.com, 2018). Lihat Gambar 3. Sedangkan, istilah "chalky"berarti suatu batuan yang mengandung kapur. Maksud dan penelitian yang ingin dicapai yaitu mengetahui efek kedalaman terhadap 
Pengaruh Chalky pada Porositas dan Permeabilitas Reservoir Batugamping Berdasarkan Uji Laboratorium Sampel Core, dari Lapangan "AR"

porositas batugamping, hubungan porositas dan permeabilitas, dan mengetahui efek/pengaruh adanya chalk pada sampel core plug batugamping terhadap nilai porositas dan permeabilitas. Hasil dari penelitian ini akan mempengaruhi rencana/strategi pengembangan lapangan (field development).
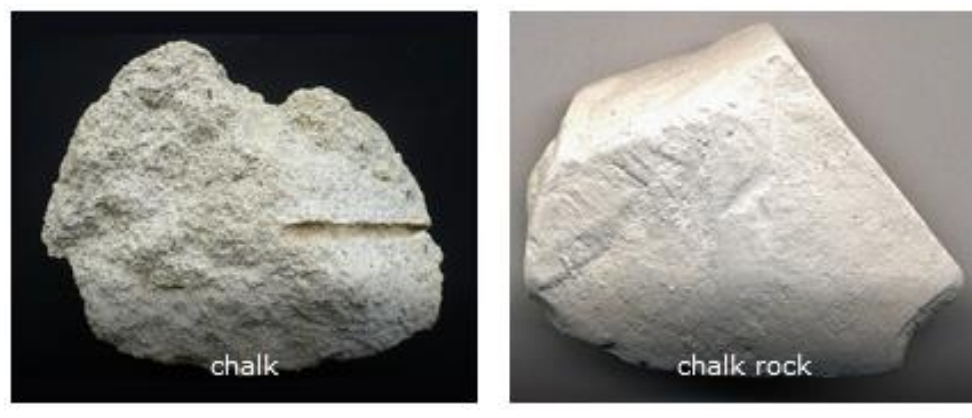

Gambar 3

Contoh batuan kapur / chalk (Geologyscience.com, 2018)

\section{Metode Penelitian}

Metode penelitian yang digunakan adalah Uji Lab dilakukan di Laboratorium Routine Core Analysis (RCAL) di PPPTMBG "Lemigas" Jakarta. Hasil uji lab dilakukan plot dalam grafik menggunakan Microsoft Excel, untuk kemudian dilakukan analisis hasilnya.

Sampel yang digunakan adalah core plug yang diambil secara horizontal dari sampel conventional core dari batuan reservoir yang mengandung minyak bumi (oil reservoir) yaitu batugamping atau limestone. Sampel tersebut tidak tersedia nama formasi batuan dan nama lapangan asalnya, sehingga diberi nama alias, yaitu lapangan "AR". Jumlah core plug yaitu 21 sampel, dan telah dilakukan preparasi sampel dan deskripsi litologi sebelumnya, sehingga sudah siap uji. Berikut ini tabel data nomor, kedalaman, dan hasil deskripsi sampel.

\section{Tabel 3}

Data Kedalaman dan deskripsi sampel core plug

\begin{tabular}{|c|c|c|}
\hline $\begin{array}{c}\text { No } \\
\text { Sampel }\end{array}$ & $\begin{array}{c}\text { Kedalaman } \\
\text { (meter) }\end{array}$ & Deskripsi Litologi \\
\hline 1 & 1088,35 & LM, lg borwn, firm, chalky, vuggy porosity \\
\hline 2 & 1088,75 & $L M$, lg borwn, $h d$, vuggy porosity, $q z$, coral fragment \\
\hline 3 & 1089,40 & LM, lg borwn, firm, chalky, vuggy porosity \\
\hline 4 & 1089,60 & $L M$, lg borwn, firm - hd, vuggy porosity, $q z$ \\
\hline 5 & 1090,35 & $L M$, lg borwn, firm - hd, vuggy porosity, qz \\
\hline 6 & 1090,70 & LM, lg borwn, firm, chalky, vuggy porosity \\
\hline 7 & 1091,25 & $L M$, lg borwn, $h d$, vuggy porosity, coral fragment \\
\hline 8 & 1091,55 & LM, lg borwn, firm, chalky, vuggy porosity \\
\hline 9 & 1092,35 & $L M$, lg borwn, $h d$, vuggy porosity, coral fragment, $q z$ \\
\hline 10 & 1092,75 & $L M$, lg borwn, firm - hd, vuggy porosity, coral fragment, $q z$ \\
\hline 11 & 1093,30 & LM, lg borwn, firm - hd, chalky, vuggy porosity \\
\hline 12 & 1093,75 & $L M$, lg borwn, $h d$, vuggy porosity, coral fragment \\
\hline
\end{tabular}




\begin{tabular}{lll}
\hline 13 & 1094,15 & LM, lg borwn, firm, chalky, vuggy porosity, coral fragment, qz \\
\hline 14 & 1094,85 & LM, lg borwn, firm - hd, vuggy porosity, coral fragment, qz \\
\hline 15 & 1095,10 & LM, lg borwn, hd, vuggy porosity \\
\hline 16 & 1095,40 & LM, lg borwn, firm - hd, chalky, vuggy porosity, qz \\
\hline 17 & 1095,85 & LM, lg borwn, firm - hd, chalky, vuggy porosity, coral fragment \\
\hline 18 & 1096,10 & LM, lg borwn, firm, chalky, vuggy porosity, coral fragment \\
\hline 19 & 1096,50 & LM, lg borwn, hd, vuggy porosity, coral fragment \\
\hline 20 & 1097,05 & LM, lg borwn, firm, chalky, vuggy porosity \\
\hline 21 & 1097,60 & $L M$, lg borwn, $h d$, vuggy porosity, coral fragment \\
\hline
\end{tabular}

Ket: warna latar belakang jingga adalah tanda sampel yang mengandung chalk (chalky)

Alat pengukur porositas dan permeabilitas menggunakan PorosimeterPermeameter merk Coveral 700, dengan menggunakan gas Helium. Lihat Gambar 4. Peralatan penunjang lainnya yaitu penggaris dan pengukur berat sampel.

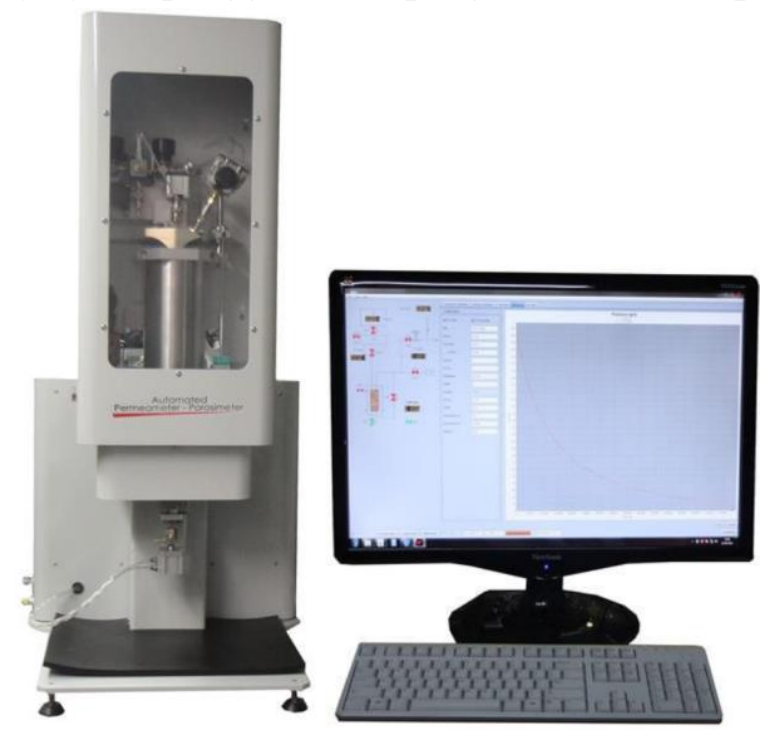

\section{Gambar 4 \\ Alat Pengukur Porositas dan Permeabilitas merk Coreval 700 (Vinci Technologies, -)}

\section{a. Tahapan Uji Lab dan Analisis}

Berikut ini tahapan uji lab dan pengolahan Data yaitu Uji Lab mengukur nilai Porositas, Uji Lab mengukur nilai Permeabilitas, Plot Grafik, kemudian Interpretasi/analisis hasil grafik.

1. Uji Lab mengukur nilai Porositas $(\varnothing)$

Untuk menghitung nilai porositas suatu sampel core plug diperlukan nilai Bulk Volume (BV) dan volume rongga pori / Pore Volume (PV). Nilai BV setiap core plug (yang berbentuk tabung pipih seperti tablet) dapat dihitung manual dengan rumus luas alas $*$ tebal core $=(22 / 7) *(0,5 * \mathrm{D})^{2} * \mathrm{~L}$.

Untuk mengukur nilai PV, digunakan alat Helium Porosimeter, dengan cara yaitu: pada proses preparasi, setiap sampel core plug dicuci dan dikeringkan, 
pada proses pencucian dan pengeringan sampel diasumsikan tidak merubah sifat fisik sampel tersebut, kemudian gas helium diinjeksikan ke dalam sampel core plug dengan tekanan 100 psi. Volume gas Helium menempati rongga pori merupakan PV.

2. Uji Lab mengukur nilai Permeabilitas (k)

Untuk menghitung nilai permeabilitas, digunakan alat Helium Permeameter, dengan cara ukuran panjang $(L)$, diameter (D), dan berat (W) setiap sampel core yang sebelumnya telah dicuci dan dikeringkan, kemudian data-data tersebut diinput pada software Coreval 700 yang terhubung dengan alat Helium Permeameter, selanjutnya sample core tersebut dimasukan kedalam core holder, menekan start dan data permeabilitas akan muncul secara otomatis pada Coreval 700 .

3. Plot Grafik

Nilai-nilai porositas ( $\varnothing)$ dan Permeabilitas (k) hasil pengukuran sebelumnya dilakukan plot dalam grafik menggunakan Microsoft Excel. Grafik yang dibuat yaitu: Porositas (\%) vs Kedalaman, Permeabilitas (k) vs Kedalaman, dan Porositas dan Permeabilitas (k).

4. Interpretasi

Interpretasi / analisis yang dilakukan pada tabel dan grafik meliputi pengelompokan/klasifikasi nilai porositas dan permeabilitas terhadap sampel yang berdasarkan hasil deskripsi sampel core plug batugamping yang mengandung chalky dan batugamping yang tidak mengandung chalky.

\section{Hasil dan Pembahasan}

Berikut adalah tabel yang menunjukkan hasil-hasil pengukuran diameter (D), Panjang (L), berat (W) hingga hasil pengukuran porositas $(\varnothing)$ dan permeabilitas (k) menggunakan porosimeter-permeameter dengan gas helium. Lihat Tabel 4.

\section{Tabel 4}

Data Kedalaman dan deskripsi sampel core plug

\begin{tabular}{|c|c|c|c|c|c|c|c|c|c|c|}
\hline \multirow{2}{*}{$\begin{array}{c}\text { No } \\
\text { Samp } \\
\text { el }\end{array}$} & $\begin{array}{c}\text { Kedalama } \\
n\end{array}$ & D & $\mathbf{L}$ & W & GD & GV & BV & PV & $\varphi$ & $\mathbf{K}_{\mathbf{H e}}$ \\
\hline & meter & mm & $\mathbf{m m}$ & gr & $\begin{array}{c}\text { gr/c } \\
\text { c }\end{array}$ & cc & cc & cc & $\%$ & $\mathbf{m D}$ \\
\hline 1 & 1088,35 & $\begin{array}{r}37,6 \\
1 \\
\end{array}$ & $\begin{array}{r}38,1 \\
1 \\
\end{array}$ & 73,10 & 2,70 & $\begin{array}{r}27,1 \\
2 \\
\end{array}$ & $\begin{array}{r}42,3 \\
4 \\
\end{array}$ & $\begin{array}{r}15,2 \\
2 \\
\end{array}$ & $\begin{array}{r}35,9 \\
5 \\
\end{array}$ & 96,04 \\
\hline 2 & 1088,75 & $\begin{array}{r}38,1 \\
1 \\
\end{array}$ & $\begin{array}{r}37,7 \\
9 \\
\end{array}$ & $\begin{array}{r}102,8 \\
4 \\
\end{array}$ & 2,70 & $\begin{array}{r}38,1 \\
2\end{array}$ & $\begin{array}{r}43,1 \\
1 \\
\end{array}$ & 4,99 & $\begin{array}{r}11,5 \\
8 \\
\end{array}$ & 1,41 \\
\hline 3 & 1089,40 & $\begin{array}{r}37,8 \\
5\end{array}$ & $\begin{array}{r}40,4 \\
4\end{array}$ & 79,43 & 2,69 & $\begin{array}{r}29,5 \\
0\end{array}$ & $\begin{array}{r}45,5 \\
0\end{array}$ & $\begin{array}{r}16,0 \\
0\end{array}$ & $\begin{array}{r}35,1 \\
7\end{array}$ & 68,86 \\
\hline 4 & 1089,60 & $\begin{array}{r}37,8 \\
3\end{array}$ & $\begin{array}{r}41,4 \\
9\end{array}$ & $\begin{array}{r}107,5 \\
0\end{array}$ & 2,68 & $\begin{array}{r}40,1 \\
2\end{array}$ & $\begin{array}{r}46,6 \\
3\end{array}$ & 6,51 & $\begin{array}{r}14,6 \\
3\end{array}$ & 0,50 \\
\hline 5 & 1090,35 & 37,9 & 38,1 & 95,74 & 2,69 & 35,5 & 43,0 & 7,48 & 17,3 & 4,39 \\
\hline
\end{tabular}




\begin{tabular}{|c|c|c|c|c|c|c|c|c|c|c|}
\hline & & 1 & 5 & & & 8 & 6 & & 7 & \\
\hline \multirow{2}{*}{6} & \multirow{2}{*}{1090,70} & 37,5 & 40,9 & \multirow{2}{*}{76,00} & \multirow{2}{*}{2,70} & 28,1 & 45,3 & 17,2 & 38,0 & 109,7 \\
\hline & & 5 & 7 & & & 1 & 7 & 6 & 4 & 8 \\
\hline \multirow[b]{2}{*}{7} & \multirow[b]{2}{*}{1091,25} & 37,7 & 40,1 & \multirow[b]{2}{*}{99,63} & \multirow[b]{2}{*}{2,70} & 36,9 & 44,9 & \multirow[b]{2}{*}{8,08} & 17,9 & \multirow[b]{2}{*}{4,19} \\
\hline & & 8 & 3 & & & 1 & 9 & & 5 & \\
\hline \multirow{2}{*}{8} & \multirow{2}{*}{1091,55} & 37,5 & 39,9 & \multirow{2}{*}{68,61} & \multirow{2}{*}{2,69} & 25,5 & 44,0 & 18,5 & 42,1 & 193,9 \\
\hline & & 1 & 0 & & & 2 & 9 & 7 & 2 & 0 \\
\hline \multirow{2}{*}{9} & \multirow{2}{*}{1092,35} & 37,9 & 41,3 & \multirow{2}{*}{$\begin{array}{r}103,1 \\
8 \\
\end{array}$} & \multirow{2}{*}{2,71} & 38,1 & 46,7 & \multirow{2}{*}{8,61} & 18,4 & \multirow{2}{*}{2,04} \\
\hline & & 3 & 5 & & & 2 & 2 & & 2 & \\
\hline \multirow{2}{*}{10} & \multirow[b]{2}{*}{1092,75} & 37,8 & 37,7 & \multirow[b]{2}{*}{94,67} & \multirow[b]{2}{*}{2,71} & 34,9 & 42,3 & \multirow[b]{2}{*}{7,44} & 17,5 & \multirow[b]{2}{*}{2,50} \\
\hline & & 1 & 5 & & & 4 & 9 & & 5 & \\
\hline \multirow{2}{*}{11} & & 37,7 & 35,1 & & & 26,9 & 39,1 & 12,2 & 31,3 & \\
\hline & 1093,30 & 3 & 9 & 12,18 & 2,10 & 4 & 9 & 8 & 2 & 61,14 \\
\hline 12 & 100375 & 37,8 & 39,0 & 0008 & 271 & 36,6 & 43,8 & 722 & 16,4 & 255 \\
\hline 12 & 1095,15 & 3 & 2 & 99,00 & 2,11 & 2 & 4 & 1,22 & 6 & L,J5 \\
\hline & & 37,7 & 39,7 & & & 29,4 & 44,6 & 15,1 & 33,9 & $86 ? 0$ \\
\hline 15 & 1094,15 & 3 & 5 & ו & 2,10 & 8 & 6 & 8 & 9 & 00,50 \\
\hline & & 37,8 & 41,6 & & & 35,7 & 46,9 & 11,1 & 23,7 & \\
\hline 14 & 1094,85 & 7 & 0 & 96,54 & 2,10 & 5 & 1 & 6 & 9 & 10,90 \\
\hline 15 & 109510 & 37,7 & 41,2 & 0650 & 270 & 35,7 & 46,3 & 10,6 & 22,8 & 070 \\
\hline 15 & 1095,10 & 9 & 0 & 90,59 & 2,10 & 8 & 9 & 1 & 6 & 9,19 \\
\hline 16 & & 37,7 & 38,8 & 0256 & 270 & 30,9 & 43,6 & 12,7 & 29,2 & 2040 \\
\hline 10 & ט & 3 & 7 & 05,50 & 2,10 & 2 & 8 & 6 & 0 & 38,40 \\
\hline 17 & 100585 & 37,7 & 40,3 & 8131 & 270 & 30,0 & 45,3 & 15,2 & 33,6 & 6642 \\
\hline 11 & 1U95,85 & 5 & 0 & 81,31 & 2,10 & 7 & 2 & 4 & 4 & 00,42 \\
\hline 18 & 109610 & 37,7 & 42,3 & 8755 & 270 & 32,3 & 47,4 & 15,0 & 31,7 & 6406 \\
\hline 10 & 1090,10 & 1 & 5 & ס & 2,10 & 8 & 1 & 3 & 1 & 04,00 \\
\hline 10 & 100650 & 37,8 & 41,9 & 102,7 & 70 & 38,0 & 47,3 & 025 & 19,5 & 424 \\
\hline 19 & 1090,30 & 8 & 2 & 5 & 2,10 & 5 & 0 & $9, \angle 0$ & 6 & 4,34 \\
\hline 20 & 1097.05 & 37,7 & 39,9 & 8433 & 271 & 31,0 & 45,0 & 13,9 & 30,9 & 101,2 \\
\hline 20 & 1U91,0 & 3 & 2 & 04,35 & 2,11 & 8 & 0 & 2 & 2 & 9 \\
\hline 21 & 109760 & 37,8 & 41,7 & 0918 & 271 & 36,6 & 47,0 & 10,3 & 22,0 & 1053 \\
\hline 21 & & 5 & 3 & 99,10 & 2,11 & 5 & 1 & 6 & 3 & 10,53 \\
\hline
\end{tabular}

Ket: warna latar belakang jingga adalah tanda sampel yang mengandung chalk (chalky)

Dari tabel diatas, kemudian dibuat grafik grafik porositas dan kedalaman, grafik permeabilitas vs kedalaman, dan grafik porositas vs permeabilitas, untuk melihat pengaruh chalky dan tanpa chalky. Untuk mempermudah analisis/interpretasi, plot /sebaran dalam grafik untuk nilai porositas dan permeabilitas batu gamping dengan adanya (with) chalky dan tanpa adanya (without) chalky dibedakan dengan warna. Lihat Gambar 5, 6, dan 7.

Dari Gambar 5, nilai porositas limestone tanpa chalky terendah yaitu 11,58\% s.d tertinggi yaitu $23,79 \%$, berdasarkan klasifikasi rentang nilai porositas termasuk dalam kelompok cukup (fair) hingga sangat baik (very good), sedangkan nilai porositas limestone dengan chalky terendah yaitu $29,20 \%$ s.d tertinggi yaitu $42,12 \%$, berarti 
Pengaruh Chalky pada Porositas dan Permeabilitas Reservoir Batugamping Berdasarkan Uji Laboratorium Sampel Core, dari Lapangan "AR"

termasuk dalam kelompok istimewa (excellent). Selain itu, tren grafik porositas limestone dengan dan tanpa chalky menunjukkan saling berkebalikan arah, terhadap kedalaman, yang berarti porositas batuan karbonat dalam kasus ini tidak berpengaruh terhadap kedalaman, namun lebih dipengaruhi kondisi litologinya (tergantung fasies dan proses saat diagenesa).

Dari Gambar 6, nilai permeabilitas limestone tanpa chalky terendah yaitu 0,5 $\mathrm{mD}$ s.d tertinggi yaitu $10,90 \mathrm{mD}$, berdasarkan klasifikasi rentang nilai permeabilitas termasuk dalam kelompok ketat (tight) hingga cukup (fair), sedangkan nilai permeabilitas limestone dengan chalky terendah yaitu 38,4 mD s.d tertinggi yaitu 193,90 $\mathrm{mD}$, berarti termasuk dalam kelompok baik ( good) hingga sangat baik (very good).

Pada Gambar 7, menunjukkan bahwa hubungan porositas dan permeabilitas adalah berbanding lurus secara eksponensial, yaitu semakin besar porositas berarti semakin besar permeabilitas, sesuai dengan yang ditulis oleh (Rukmana et al., 2012). Dari Gambar 5, 6 dan 7, dapat diambil kesimpulan bahwa porositas dan permeabilitas limestone dengan chalky lebih baik dibanding limestone tanpa chalky.

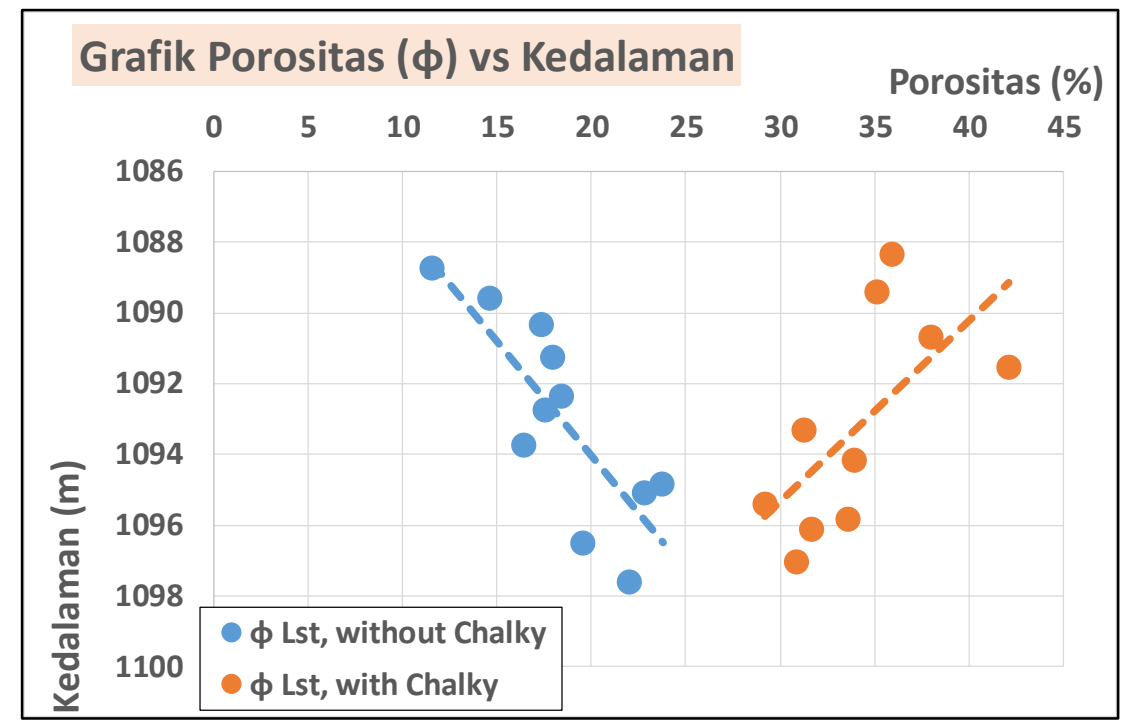

Gambar 5

Grafik kedalaman (m) vs porositas Lst / limestone dengan chalky (biru), dan grafik kedalaman (m) vs porositas Lst / limestone tanpa chalky (jingga) 


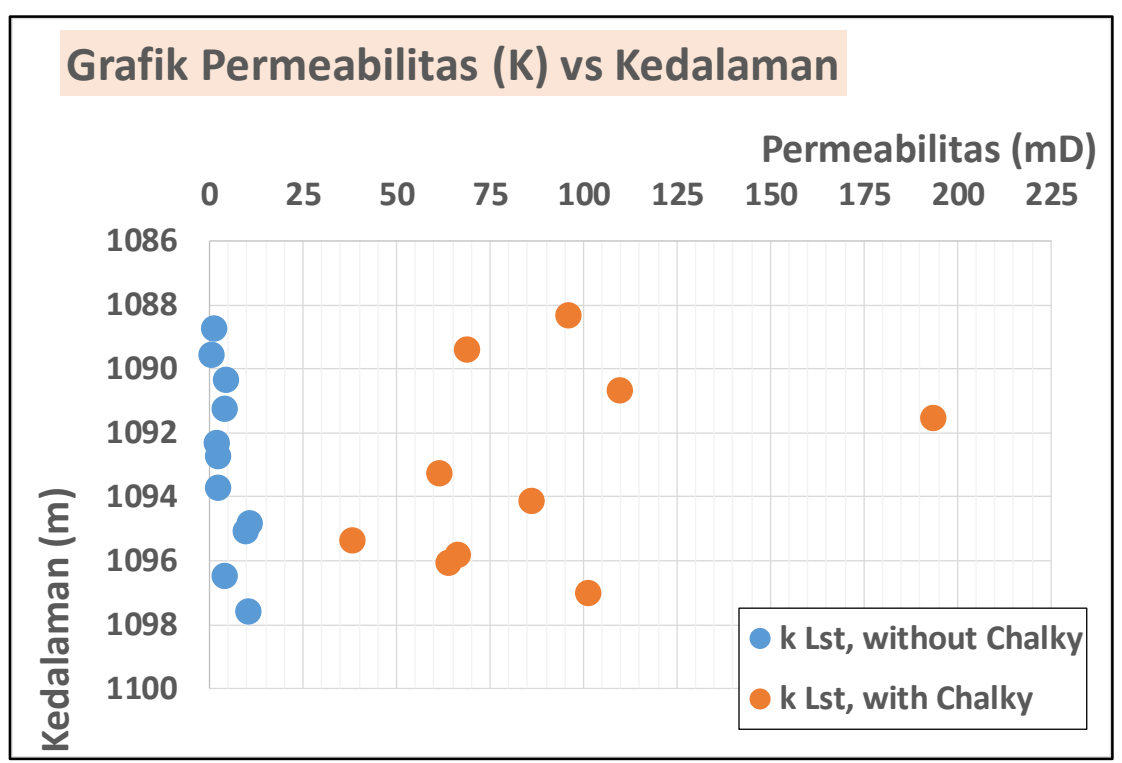

Gambar 6

Grafik kedalaman (m) vs permeabilitas Lst / limestone dengan chalky (biru), dan grafik kedalaman (m) vs permeabilitas Lst / limestone tanpa chalky (jingga)

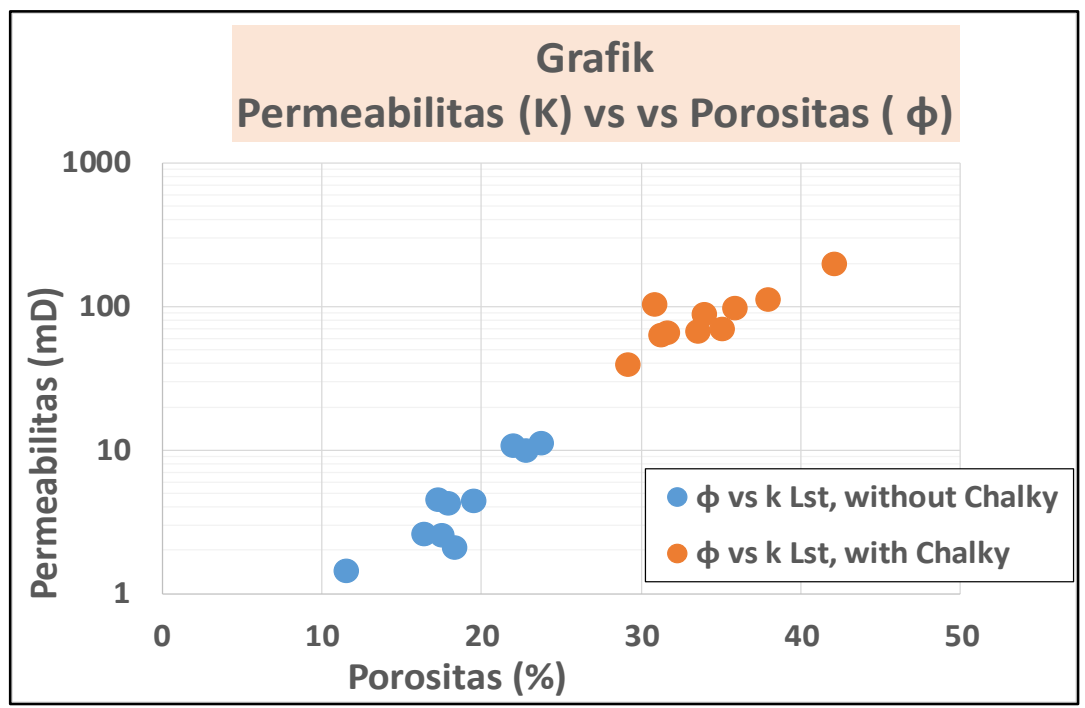

Gambar 7

Grafik permeabilitas (md) vs porositas (\%) dengan dan tanpa chalky, berbanding lurus.

\section{Kesimpulan}

Dari semua penjelasan diatas, dapat disimpulkan beberapa poin berikut:

1. Nilai Porositas batuan karbonat dalam kasus ini tidak berpengaruh terhadap kedalaman, namun lebih dipengaruhi kondisi litologinya (tergantung fasies dan proses saat diagenesa).

2. Hubungan porositas dan permeabilitas dalam kasus ini adalah berbanding lurus secara eksponensial, yaitu semakin besar porositas berarti semakin besar permeabilitas 
Pengaruh Chalky pada Porositas dan Permeabilitas Reservoir Batugamping Berdasarkan Uji Laboratorium Sampel Core, dari Lapangan "AR"

3. Nilai porositas dan permeabilitas limestone dengan kehadiran chalky lebih baik dibanding limestone tanpa kehadiran chalky. 


\section{Bibliography}

Asgarinezhad, Y., Asgarinezhad, M., Tokhmechi, B., Kamkar-Rouhani, A., \& Sherkati, S. (2016). Detecting vuggy porosity in carbonate reservoirs by well logs. Journal of Petroleum Exploration and Production Technology, 6(1), 25-31.

Hiatt, E. E., \& Kyser, T. K. (2000). Links between depositional and diagenetic processes in basin analysis: porosity and permeability evolution in sedimentary rocks. Fluids and Basin Evolution. Mineralogical Association of Canada, Short Course, 28, 63-92.

Kadhim, F. S., \& Al-Sudani, H. (2020). Petrophysical Properties of Khasib Formation in East Baghdad Oil Field Southern Area. Iraqi Journal of Chemical and Petroleum Engineering, 21(4), 41-48. https://doi.org/10.31699/IJCPE.2020.4.5

Koesoemadinata, R. P. (1980). Geologi Minyak dan Gas Bumi, Jilid 1 dan 2. Institut Teknologi Bandung: Bandung.

Ltd, S. C. P. (2016). Quantifying carbonate porosity - Choquette and Pray (1970) textures and subsequent modifications.

Monroe, S J., Wicander R., dan H. R. (2007). Physical Geology: Exploring the Earth 6th. Thomson Brooks/Cole, a part of The Thomson Corporation.

Nichols, G. (2009). Sedimentology and stratigraphy. John Wiley \& Sons.

Noventiyanto, A. (2011). Identifikasi Penyebaran Porositas pada reservoir karbonat lapangan " $A S$ " Dengan Mengintegrasikan Analisa Fasies Pengendapan, Proses Diagenesa dan Atribut Impedansi Akustik.

Rukmana, D., Kristanto, D., \& Cahyoko Aji, V. D. C. (2012). Teknik Reservoir: Teori dan Aplikasi. Sadan Pelaksana Kegiatan Usaha Hulu Minyak dan Gas Bumi (BPMIGAS) dengan ....

Widarsono, B. (2008). Hubungan antara Porositas dengan Kedalaman untuk ReservoirReservoir Batupasir di Indonesia Barat. Lembaran Publikasi Minyak Dan Gas Bumi, 42(3), 11-17.

Yu, Y., \& Menouar, H. (2015). An experimental method to measure the porosity from cuttings: Evaluation and error analysis. SPE Production and Operations Symposium.

Geologyscience.com. (2018). Chalk. https://geologyscience.com/rocks/sedimentaryrocks/chalk/ Diakses tanggal 5 Mei 2021 